\title{
CXC chemokine receptor type 4 in systemic lupus
}

Emil Nashi' ${ }^{1}$, Joyce Rauch ${ }^{3}$, James J. Goedert ${ }^{2}$, Christian A. Pineau ${ }^{3}$ and Sasha Bernatsky ${ }^{3,4^{*}}$

*Correspondence: sasha.bernatsky@mcgill.ca

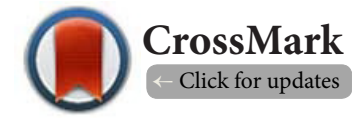

'Department of Immunology and Allergy, McGill University Health Centre, Montréal, Canada.

${ }^{2}$ Division of Cancer Epidemiology and Genetics, Infections and Immunoepidemiology Branch, National Cancer Institute, Rockville, MD, USA.

${ }^{3}$ Division of Rheumatology, McGill University Health Centre, Montréal, Canada.

${ }^{4}$ Division of Clinical Epidemiology, McGill University Health Centre, Montréal, Canada.

\section{Dear editor}

There is increasing interest in the complex links between the immune system and cancer risk. Early data indicated decreased breast cancer risk for women with human immunodeficiency virus (HIV) infection compared to the general population [1] A case-control study further showed that lower breast cancer risk in women with HIV was significantly and independently linked to infection with HIV strains that bind to CXC chemokine receptor type 4 (CXCR-4) [2]. In most normal tissues, CXCR4 is not generally expressed (or is expressed at very low levels), but is found on some types of cancer cells, including breast cancer. CXCR4 is also expressed on abnormal precancerous breast cells. The authors of the case-control study thus hypothesized that, in women with HIV, involution of the abnormal precancerous cells is mediated by binding of CXCR4.

Systemic lupus erythematosus (SLE) is an autoimmune rheumatic disease which is associated with a strikingly decreased risk of certain malignancies including breast cancers [3]. Given the data suggesting that the decreased risk of breast cancer in women with HIV infection is mediated by interactions with CXCR4, we hypothesized that the sera of women with SLE actively binds to CXCR4 antigen, which might invoke a pathway through which the lower breast cancer risk in SLE is mediated.

\section{Methods}

We performed preliminary analyses using banked sera, drawn from women with SLE who are annually followed at the McGill University Health Centre (MUHC) lupus clinic, which currently numbers over 650 . We randomly selected 19 of these patients with SLE, to assess whether SLE sera demonstrated active binding to CXCR4 antigen, in an enzyme-linked immunosorbent assay (ELISA) test. Human recombinant CXCR4 was purchased from Abnova (catalog \# H00007852-P01). The secondary antibody was alkaline phosphatase-conjugated lgG $F\left(a b^{\prime}\right) 2$ fragment of donkey anti-human-lgG and was purchased from Jackson Immunoresearch (catalog \# 709-056-098). Phosphatase substrate was purchased from Sigma-Aldrich (Catalog \# S0942) and colorimetric detection was at $405 \mathrm{~nm}$. We also compared results of the ELISA test in these SLE patients, to that of banked serum from 23 healthy controls.

\section{Results}

In the assay for CXCR4 antigen binding, at 20 minutes, both the mean and median optical density of sera diluted 1:40 was slightly but non-significantly higher, in SLE patients versus controls. For the entire sample, mean value in SLE was 0.461, $95 \%$ confidence interval, $\mathrm{Cl} 0.116,0.638$ (while the average for controls was $0.435,95 \% \mathrm{Cl} 0.101,0.605)$ and the median value in SLE was 0.493 (0.356 in controls). Limited to Caucasians only, the mean value in SLE was 0.543 (while the average for controls was 0.459 ) and the median value in SLE was 0.566 (0.423 in controls).

\section{Discussion}

We present a novel hypothesis of how the lower risk of breast cancer risk in SLE may be mediated by CXCR4 binding on precancerous cells. Our data suggest that SLE patients have measurable levels of antibodies against CXCR4. Although our preliminary data only suggest a slight trend towards higher mean and median titers in lupus patients than in controls, it would be of interest to determine whether SLE patients have higher levels of functional anti-CXCR4 antibodies that either activate or block signalling through this receptor.

\section{Competing interests}

The authors declare that they have no competing interests.

\section{Authors' contributions}

\begin{tabular}{|l|c|c|c|c|c|}
\hline Authors' contributions & EN & JR & JJG & CAP & SB \\
\hline Research concept and design & $\checkmark$ & $\checkmark$ & $\checkmark$ & $\checkmark$ & $\checkmark$ \\
\hline Collection and/or assembly of data & $\checkmark$ & $\checkmark$ & -- & $\checkmark$ & $\checkmark$ \\
\hline Data analysis and interpretation & $\checkmark$ & $\checkmark$ & $\checkmark$ & $\checkmark$ & $\checkmark$ \\
\hline Writing the article & $\checkmark$ & $\checkmark$ & $\checkmark$ & $\checkmark$ & $\checkmark$ \\
\hline Critical revision of the article & $\checkmark$ & $\checkmark$ & $\checkmark$ & $\checkmark$ & $\checkmark$ \\
\hline Final approval of article & $\checkmark$ & $\checkmark$ & $\checkmark$ & $\checkmark$ & $\checkmark$ \\
\hline
\end{tabular}


Nashi et al. Journal of Autoimmunity and Cell Responses 2014, http://www.hoajonline.com/journals/pdf/2054-989X-1-2.pdf

\section{Acknowledgement}

The authors thank Rebecca Subang for technical assistance.

Publication history

Editors: Chrong-Reen Wang, National Cheng Kung University

Hospita, China.

Amedeo Amedei, Azienda Ospedaliera Universitaria Careggi, Italy.

Received: 01-Apr-2014 Final Revised: 22-May-2014

Accepted: 28-May-2014 Published: 04-Jun-2014

\section{References}

1. Goedert JJ, Schairer C, McNeel TS, Hessol NA, Rabkin CS and Engels EA. Risk of breast, ovary, and uterine corpus cancers among 85,268 women with AIDS. Br J Cancer. 2006; 95:642-8. | Article | PubMed Abstract | PubMed Full Text

2. Hessol NA, Napolitano LA, Smith D, Lie Y, Levine A, Young $M$, Cohen $M$ Minkoff H, Anastos K, D'Souza G, Greenblatt RM and Goedert JJ. HIV tropism and decreased risk of breast cancer. PLoS One. 2010; 5:e14349. | Article | PubMed Abstract | PubMed Full Text

3. Bernatsky S, Ramsey-Goldman R, Labrecque J, Joseph L, Boivin JF, Petri M, Zoma A, Manzi S, Urowitz MB, Gladman D, Fortin PR, Ginzler E, Yelin E, Bae SC, Wallace DJ, Edworthy S, Jacobsen S, Gordon C, Dooley MA, Peschken CA, Hanly JG, Alarcon GS, Nived O, Ruiz-Irastorza G, Isenberg D, Rahman A, Witte T, Aranow C, Kamen DL, Steinsson K, Askanase A, Barr S, Criswell LA, Sturfelt G, Patel NM, Senecal JL, Zummer M, Pope JE, Ensworth S, El-Gabalawy H, McCarthy T, Dreyer L, Sibley J, St Pierre Y and Clarke AE. Cancer risk in systemic lupus: an updated international multicentre cohort study. J Autoimmun. 2013; 42:130-5. | Article | PubMed Abstract | PubMed Full Text

\section{Citation:}

Nashi E, Rauch J, Goedert JJ, Pineau CA and Bernatsky S. CXC chemokine receptor type 4 in systemic lupus. J Autoimmun Cell Response. 2014; 1:2. http://dx.doi.org/10.7243/2054-989X-1-2 